\title{
Leptin receptor signaling is required for high-fat diet-induced atrophic gastritis in mice
}

Kyoko Inagaki-Ohara ${ }^{1,2,3^{*}}$, Shiki Okamoto ${ }^{2}$, Kazuyo Takagii ${ }^{2}$ Kumiko Saito ${ }^{2}$, Seiya Arita ${ }^{3}$, Lijun Tang ${ }^{2}$, Tetsuji Hori ${ }^{4}$, Hiroaki Kataoka ${ }^{5}$, Satoshi Matsumoto ${ }^{4}$ and Yasuhiko Minokoshi ${ }^{2}$

\begin{abstract}
Background: Obesity increases the risk for malignancies in various tissues including the stomach. Atrophic gastritis with precancerous lesions is an obesity-associated disease; however, the mechanisms that underlie the development of obesity-associated atrophic gastritis are unknown. Leptin is a hormone derived from stomach as well as adipose tissue and gastric leptin is involved in the development of gastric cancer. The aim of the current study is to investigate the involvement of leptin receptor signaling in the development of atrophic gastritis during diet-induced obesity.

Methods: Male C57BL/6, ob/ob and db/db mice were fed a high-fat diet (HFD) or a control diet (CD) from 1 week to 5 months. Pathological changes of the gastric mucosa and the expression of molecules associated with atrophic gastritis were evaluated in these mice.

Results: HFD feeding induced gastric mucosal hyperplasia with increased gastric leptin expression. Mucosal hyperplasia was accompanied by a higher frequency of Ki67-positive proliferating cells and atrophy of the gastric glands in the presence of inflammation, which increased following HFD feeding. Activation of ObR signalingassociated molecules such as ObR, STAT3, Akt, and ERK was detected in the gastric mucosa of mice fed the HFD for 1 week. The morphological alterations associated with gastric mucosal atrophy and the expression of Muc2 and $\mathrm{Cd \times 2}$ resemble those associated with human intestinal metaplasia. In contrast to wild-type mice, leptindeficient ob/ob mice and leptin receptor-mutated $d b / d b$ mice did not show increased $C d \times 2$ expression in response to HFD feeding.
\end{abstract}

Conclusion: Together, these results suggest that activation of the leptin signaling pathway in the stomach is required to develop obesity-associated atrophic gastritis.

Keywords: Leptin, Atrophic gastritis, High-fat diet, Obesity

\section{Background}

Gastric carcinoma (GC) typically arises on a background of atrophic gastritis, intestinal metaplasia, and dysplasia of gastric mucosa, and is the second leading cause of cancer-related deaths worldwide [1]. Obesity augments the risk of a higher prevalence of gastritis [2,3], atrophic gastritis [4-6], and gastric cardia adenocarcinoma [7-9].

\footnotetext{
* Correspondence: k-inagaki@pu-hiroshima.ac.jp

${ }^{1}$ Research Institute, National Center for Global Health and Medicine (NCGM),

1-21-1, Toyama Shinjuku, Tokyo 162-0052, Japan

${ }^{2}$ Division of Endocrinology and Metabolism, Department of Developmental

Physiology, National Institute for Physiological Sciences (NIPS), 38

Nishigonaka Myodaiji, Okazaki, Aichi 444-8585, Japan

Full list of author information is available at the end of the article
}

Infection with Helicobacter pylori, a bacterium that infects humans and colonizes the stomach, is the predominant cause of precancerous lesions in the mucosal lining of the stomach [10]. Although $H$. pylori infection is not confined to morbidly obese patients, obesity increases the prevalence of chronic gastritis and GC [2]. Furthermore, obesity is not only a risk factor for certain tumors but is also associated with an increased mortality rate [11]. Thus, obesity potentially affects the development of gastritis into gastric tumorigenesis. Therefore, it is imperative to identify signaling molecules associated with both obesity and precancerous lesions to aid in the management of high-risk individuals. 
Leptin, a product of the obese $(o b)$ gene, is primarily produced by adipocytes and acts on its receptor (ObR) in the hypothalamus to suppress food intake and increase energy expenditure [12]. ObR belongs to the class I cytokine receptor family, and its structure is highly homologous to that of gp130, the common signal-transducing receptor for the interleukin-6 (IL-6) family of cytokines [13]. Of the six alternate splice variants of ObR, only the long isoform, ObRb, transduces a signal cascade that activates downstream Janus kinase 2 and signal transducer and activator of transcription 3 (JAK2-STAT3), phosphoinositide 3-kinase (PI3K), and extracellular signal-regulated kinase 1/2 (ERK1/2) [14]. In addition to its role in energy homeostasis, leptin exerts pleiotropic effects on angiogenesis, hematopoiesis, and immunity as well [14]. Leptin and ObR are also expressed in various tissues including the gastrointestinal tract [15]. Additionally, the stomach can spontaneously express leptin and ObR, leading to the augmentation of leptin receptor signaling in the stomach during GC development [16-18]. We have previously demonstrated the significance of leptin signaling in the stomach and its role in the development of intestinal-type gastric tumor using a murine model [19]. Dysfunction of central sympathetic regulation of leptin signaling promotes leptin resistance. Despite high levels of circulating plasma leptin, obese individuals do not respond to its appetite-suppressing effects, indicating their leptin resistance [20]. Because leptin is crucial to the development of gastrointestinal malignancies and provides a link between obesity and tumorigenicity [17], a better understanding of the dysregulation of gastric leptin signaling and its role in obesity-induced gastric pathology is necessary.

\section{Methods}

\section{Animals and diets}

Male C57BL/6J (wild-type: WT), $o b / o b$, and $d b / d b$ mice (CLEA Japan, Tokyo, Japan) were studied at 7 weeks of age. The animals were housed individually in plastic cages at $24{ }^{\circ} \mathrm{C} \pm 1{ }^{\circ} \mathrm{C}$ with lights on from 0600 to $1800 \mathrm{~h}$. The mice were provided with either a control-diet (CD, $10 \%$ of calories from fat, D12450J) or a high-fat diet (HFD, $60 \%$ of calories from fat, D12492) (Research Diets Inc., New Brunswick, NJ) and water ad libitum. The ethics committee for animal experiments of the National Institute for Physiological Sciences approved all animal experiments.

\section{Histopathological analysis of the gastric mucosa}

Paraffin-embedded gastric sections of $10 \%$ formalin-fixed tissues were obtained from the HFD- and CD-fed mice and were stained with hematoxylin and eosin (H\&E), and assessed for alterations in the gastric mucosa. The assessment of mucosal alterations in the stomach was based on a summation of scores for hyperplasia ( 0 , non-substantial alteration; 1 , low; 2 , moderate; 3 , high), cell infiltration ( 0 , non-substantial alteration; 1 , low; 2 , moderate; 3 , high), loss of gastric glandular cells ( 0 , non-substantial alteration; 4 , low; 5 , moderate; 6 , high), Alcian blue staining ( 0 , nonsubstantial alteration; 4 , focal; 5 , diffuse; 6 , very strong diffuse), and dysplasia (0, non-substantial alteration; 7, low). Each criterion was independently blind-scored by two individuals using criteria that were previously defined [19].

\section{Intragastric $\mathrm{pH}$ measurements}

Gastric $\mathrm{pH}$ was measured according to a published method [21]. In brief, mice were sacrificed after anesthetization by carbon dioxide inhalation. Following stomach removal, the gastric lumen was removed and washed with $0.5 \mathrm{ml}$ saline $(150 \mathrm{mM}, \mathrm{pH} 7.0)$, and the $\mathrm{pH}$ of the collected gastric fluid was measured using a $\mathrm{pH}$ meter (Mettler, Toledo, $\mathrm{OH}$ ).

\section{Immunohistochemical analysis}

Paraffin-embedded sections of $10 \%$ formalin-fixed tissues were stained either with $H \& E$ or with periodic-acid Schiff (PAS) and Alcian blue. For antigen retrieval, deparaffinized and rehydrated specimens were treated with $3 \%$ hydrogen peroxide in methanol to block endogenous peroxidase activity and then were heated in a microwave using a Retrievagen A kit (BD Biosciences, San Jose, CA), followed by overnight incubation with primary antibodies (Abs) at $4{ }^{\circ} \mathrm{C}$ as listed in Additional file 1: Table S1. Subsequently, the slides were stained with a biotinylated anti-rabbit IgG or anti-goat IgG Ab and streptavidin-labeled peroxidase using a Histofine SAB-PO kit (Nichirei Biosciences Inc., Tokyo, Japan) and developed using 3, 3'-diaminobenzidine (DAB) solution (ImmPact ${ }^{\mathrm{TM}} \mathrm{DAB}$, Vector Laboratories, Burlingame, CA) according to the manufacturer's protocol, followed by hematoxylin counterstaining. For immunofluorescence staining, the slides were incubated with the primary Abs (Additional file 1: Table S1) and then reacted with Alexa 488-conjugated rabbit or mouse IgG Ab or Alexa 556conjugated goat IgG Ab, as appropriate. The stained slides were mounted using ProLong Gold Antifade reagent with 4',6-diamidino-2-phenylindole (DAPI) (Life Technologies, Carlsbad, CA) for detection using a fluorescence microscope (Olympus, Tokyo, Japan).

\section{Western blot analysis}

Gastric epithelial cells were isolated and prepared according to a modification of a previously published method [22]. Dissected small segments of the stomach were agitated at room temperature for $10 \mathrm{~min}$ in a Hank's balanced salt solution (HBSS) (Thermo Fisher Scientific Inc., Waltham, MA) medium containing $1 \mathrm{mM}$ DTT. After removal of the supernatant, the tissues were stirred at $37{ }^{\circ} \mathrm{C}$ for $10 \mathrm{~min}$ in HBSS containing 
$10 \mathrm{mM}$ EDTA. After removal of the supernatant, the tissue suspension was passed through a nylon mesh to remove debris and centrifuged through a $25 / 40 \%$ discontinuous Percoll (Sigma-Aldrich, St. Louis, MO) gradient at $600 \times g$ at $20{ }^{\circ} \mathrm{C}$ for $20 \mathrm{~min}$. The cells collected from the interface of $25 / 40 \%$ were the epithelial cells. Lysates were prepared from tissues and cells and analyzed by western blotting, according to a previously published method [23]. The Abs used in western blotting are summarized in Additional file 1: Table S1.

\section{Laser-capture microdissection}

The above-described paraffin-embedded gastric tissues were cut into 6 - $\mu \mathrm{m}$-thick sections and mounted onto membrane slides (MembraneSlide 1.0 PEN, Carl Zeiss Microscopy, LLC, Thornwood, NY). Paraffin was removed by rinsing the sections with xylene, after which the sections were immersed in a series of $100 \%$ to $70 \%$ ethanol baths and air-dried. Mucosal sections of gastric epithelia were cut and collected onto AdhesiveCaps (PALM, Microlaser Technologies, Bernried, Germany) by a lasercapture microdissection (LMD) system (PALM MB-III, Microlaser Technologies).

\section{Quantitative reverse transcription-polymerase chain reaction (qRT-PCR)}

Total RNA from the LMD samples and from murine gastric mucosa was extracted using AllPrep FFPE DNA/ RNA and RNeasy Mini kits (Qiagen, Valencia, CA), respectively, according to the manufacturer's protocols. cDNA was synthesized from approximately 100-200 ng RNA from the LMD sections or 1-2 $\mu \mathrm{g}$ RNA from gastric mucosal cells using the ReverTra Ace qPCR RT Kit (TOYOBO, Co., Ltd., Osaka, Japan) according to the manufacturer's protocol. qRT-PCR was carried out using the Power SYBR Green PCR Master Mix (Life Technologies, Carlsbad, CA) with specific primer sets (400 nM at the final concentration, Additional file 2: Table S2) according to the manufacturers' protocol. Relative changes in gene expression were calculated using the $\Delta \Delta \mathrm{Ct}$ method, and the $18 \mathrm{~S}$ rRNA gene was used for normalization.

\section{Quantitative analysis of immunohistochemical staining}

For microscopic measurements, leptin-stained gastric mucosa samples were photographed using a microscope (Olympus), and quantitative analysis was performed using ImageJ software (http://rsb.info.nih.gov/ij/index.html). Mucosal height was measured between the base of the gastric glands and the neck zone.

\section{Plasma assay}

Serum was collected from blood obtained by cardiocentesis under anesthetization and stored at $-80{ }^{\circ} \mathrm{C}$. Insulin (Mouse Insulin ELISA kit, Shibayagi, Gunma, Japan), leptin (Leptin
ELISA, Millipore, St. Charles, MO), glucose (Glucose CII-test, Wako, Osaka, Japan), and non-esterified fatty acid (NEFA) (NEFA C-test, Wako) levels in the sera were measured according to the manufacturers' protocols.

\section{Statistical analysis}

The Mann-Whitney $U$ test and the Kruskal-Wallis test were used to determine significant differences. A $p$-value of less than 0.05 was considered significant. Statistical analyses were performed using Prism software version 6 (GraphPad, San Diego, CA, USA).

\section{Results}

\section{HFD-fed mice develop atrophic gastritis}

To determine how diet-induced obesity affects the pathogenesis of gastric mucosa, C57BL/6 mice were fed either HFD (60\% calories from fat) or CD (10\% calories from fat) and the histological changes of the gastric mucosa were examined in a time-dependent manner. Compared to the CD-fed mice, the HFD-fed mice exhibited rapid weight gain at a rate of $>2$ g per week during the first 12 weeks. Thereafter, a moderate increase of $1 \mathrm{~g}$ per week was observed from 12 to 20 weeks (Fig. 1a). The cardial mucosa showed hyperplasia at 1 week, prior to any significant difference in body weight gain between the CD- and HFD-fed groups $(1.5 \pm 0.29$ in CD vs. $1.8 \pm 0.4$ in HFD, $p>0.05$ ) (Fig. $1 \mathrm{a}$ and $1 \mathrm{~b}$ ). At 3 weeks, a reduced parietal cell number and morphological alterations of the foveola in the stomach were observed, followed by glandular metaplasia and a complete loss of zymogenic and parietal cells at 12 weeks after the initiation of HFD feeding (Fig. 1b). Although the hyperplastic change of the gastric foveolar epithelium was seen at 1 week in the HFD-fed mice, few $\mathrm{CD} 45^{+}$infiltrated cells were present in HFD-fed mice (Fig. $1 \mathrm{~b}$ and $1 \mathrm{~d}$ ). However, after 3 weeks of feeding, a substantial amount of infiltrated cells were seen to have invaded the interglandular and basal spaces in accordance with the development of hyperplasia (Fig. 1b and 1d). In the antrum, slight mucosal hyperplasia was observed in HFD-fed mice at 1 week after diet initiation. Both the cardia and antrum displayed a replacement of normal glandular cells such as parietal and $G$ cells with atypical and irregular cells after 3 weeks of HFD feeding (Fig. 1b). Furthermore, mildly dysplastic epithelia, with cells showing enlarged nuclei, nuclear pseudostratification, and distinct nucleoli, became apparent in the hyperplastic lesions of HFD-fed mice at 12 weeks after feeding (Fig. 1c). A high frequency of Ki67-positive proliferating cells was observed in the hyperplastic and dysplastic stomach lesions of the HFD-fed mice, whereas these cells presented a defined proliferating zone in the CD-fed mice (Fig. 1e). These alterations rapidly progressed by 8 weeks of feeding (Fig. 2c). At 20 weeks of feeding, the folds of the glossy gastric mucosa were flat with a pale appearance, and polyp-like 


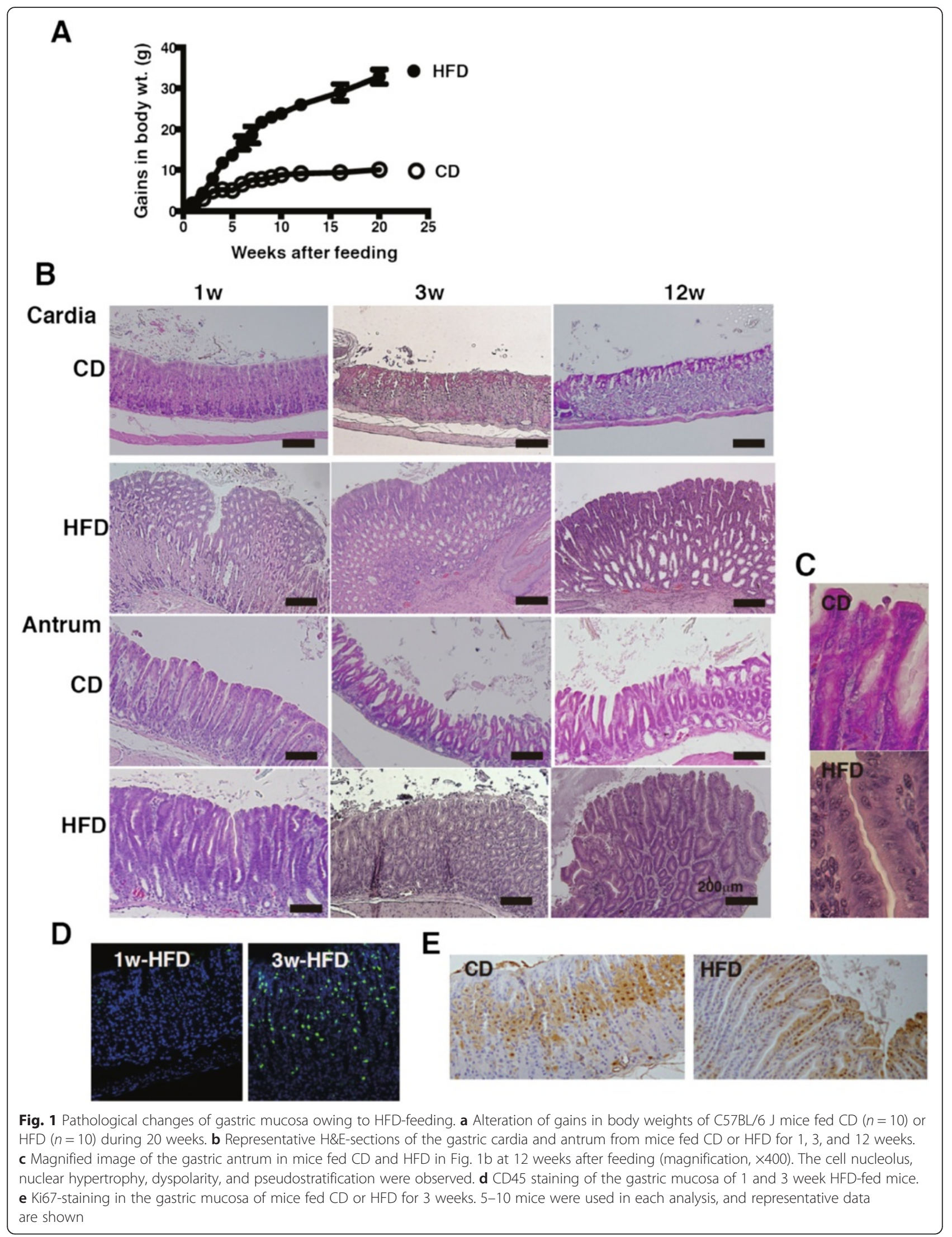



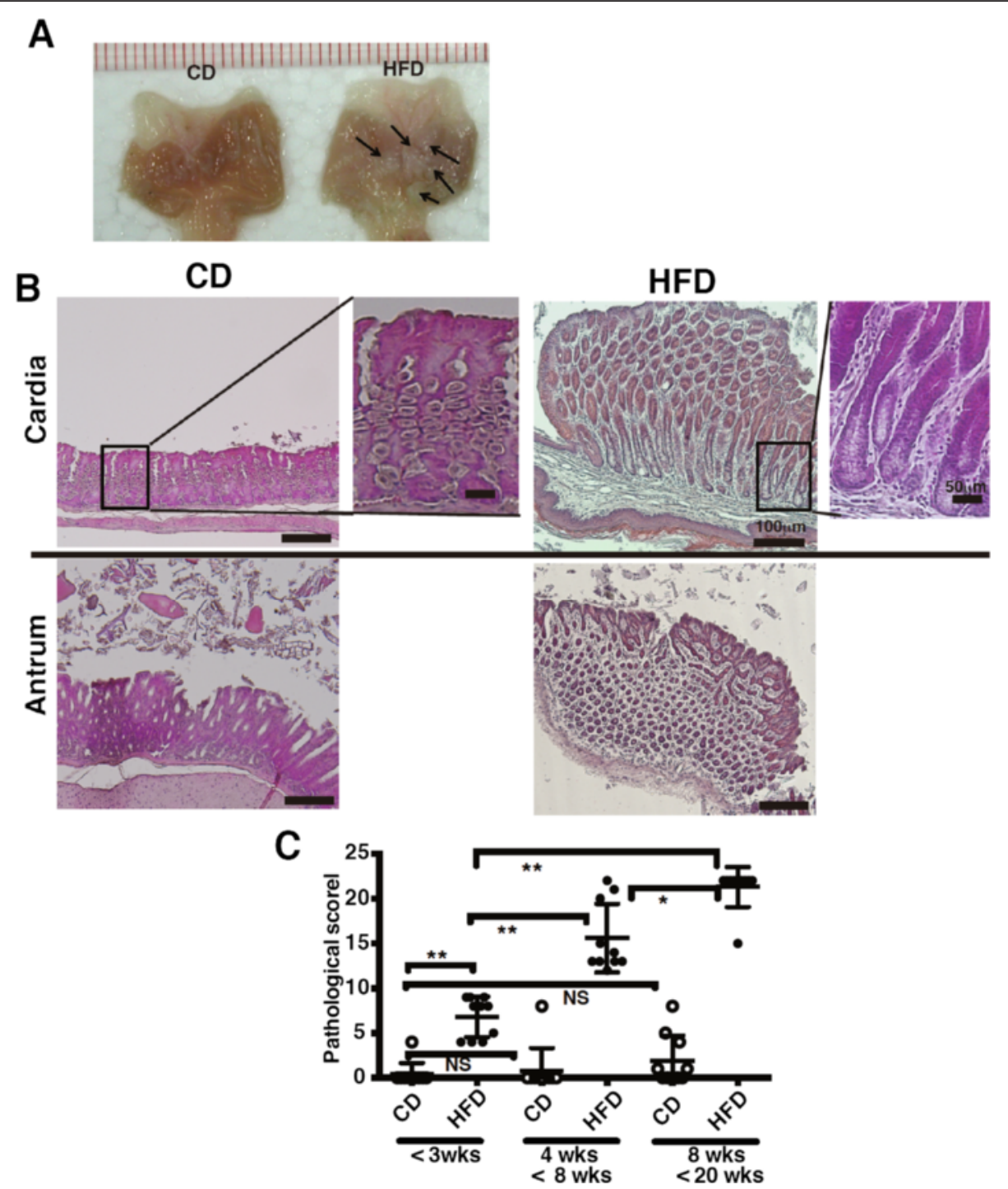

Fig. 2 Development of gastric mucosal atrophy in diet-induced obese mice. a The gastric lumen was opened along the outer curvature of mice fed CD or HFD for 20 weeks. Arrows indicate the polyp-like lesions in the stomach of HFD-fed mice. $\mathbf{b}$ Representative H\&E-sections of the gastric cardia and antrum from mice fed CD or HFD for 20 weeks. c The histological scores from the stomachs of mice fed CD or HFD ( $<3$ weeks, 4-8 weeks, 8-20 weeks of feeding; 10 mice per group) were graded according to the diagnostic criteria described in the Methods. Results were analyzed by the Kruskal-Wallis test, followed by a Dunn's multiple comparison test. ${ }^{*} p<0.05$, ${ }^{*} p<0.01$, NS; not significant

lesions were observed in the cardia and fundic regions of HFD-fed mice (arrows in Fig. 2a). At this point, the cell infiltration was complete, and the normal gastric glands were replaced by intestinal crypt-like structures at the cardial basal mucosa of HFD-fed mice (Fig. 2b). These results indicate that HFD-feeding alters gastric epithelial integrity even at the early phase of feeding and suggest that the occurrence of mucosal hyperplasia in the stomach was initiated by inflammation-independent events.

\section{Upregulation of intestinal markers in the gastric mucosa} We further examined whether the gastric mucosa in HFD-fed mice exhibited features of intestinal mucosa.
We observed that the frequency of Alcian blue-stained goblet cells, which are intestinal mucus cells, increased as they spread across the gastric mucosa in HFD-fed mice (Fig. 3a). Muc2, an intestinal type of mucin, was ectopically expressed in the gastric mucosa only of HFD-fed mice (Fig. 3a), indicating that gastric mucin was converted to the intestinal type as has been observed in most human gastric carcinomas [24]. The results of gene expression analysis were consistent with the immunohistological findings. The mRNA expression of $M u c 2$ and Tff3 (a peptide co-expressed with Muc2) increased, whereas that of the gastric-type mucins, $M u c 1, M u c 5 a c$, and $M u c 6$, remained unaltered or decreased in the 


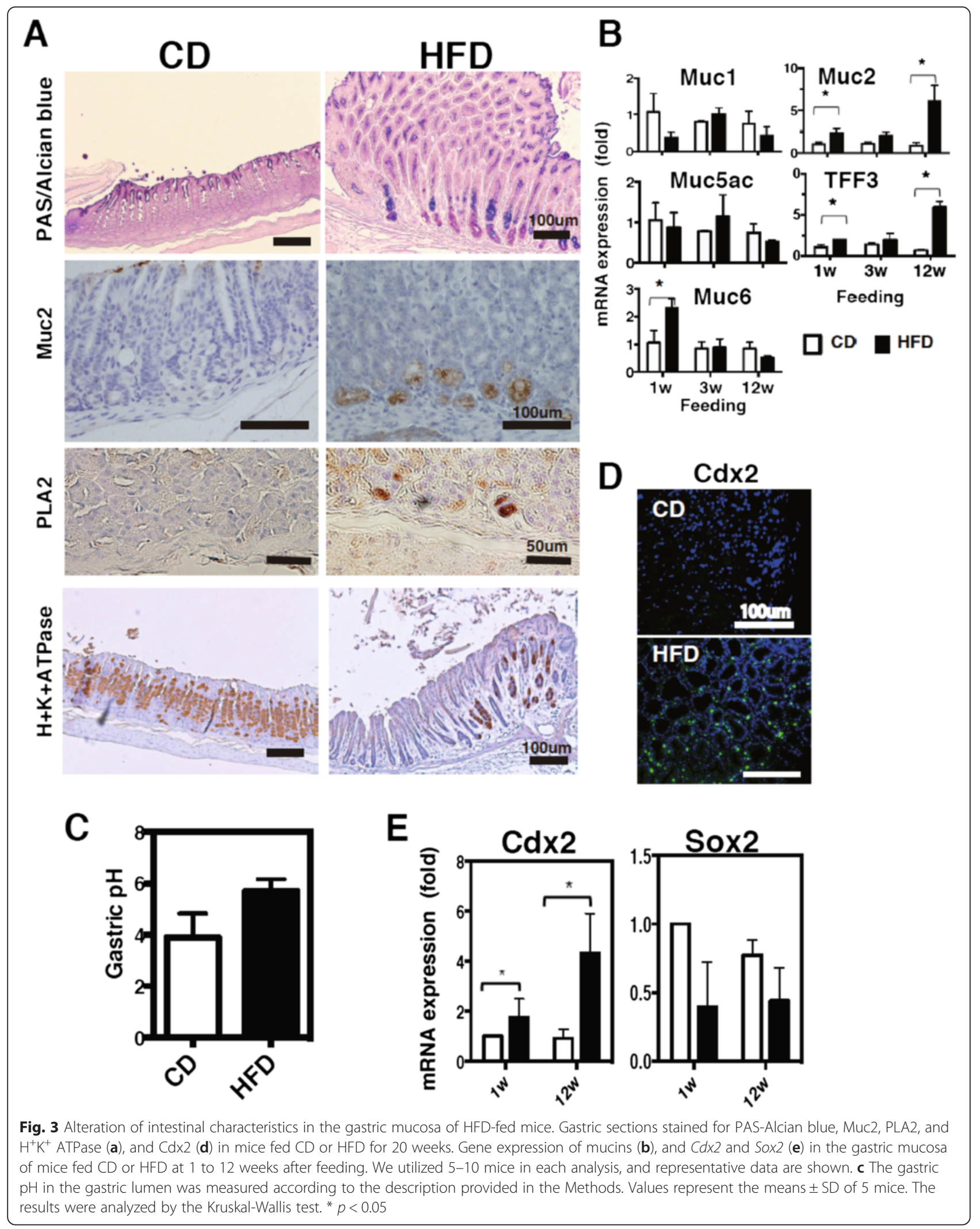


stomachs of HFD-fed mice (Fig. 3b). The cardia of HFDfed mice also showed ectopic expression of phospholipase A2 (PLA2), an intestinal Paneth cell marker (Fig. 3a). In contrast, the expression of $\mathrm{H}^{+} \mathrm{K}^{+}$-ATPase, a marker of parietal cells that secrete gastric acid, decreased with a concurrent elevation of gastric $\mathrm{pH}$ in the HFD-fed mice (Fig. 3a and 3c). In addition, the deregulation of transcription factor expression transposes into a metaplastic phenotype. Accordingly, the mRNA expression of $C d x 2$, an intestinal master transcription factor that is a marker of intestinal metaplasia, was higher in HFD-fed mice at 1 week (Fig. 3e). Furthermore, $C d x 2$ mRNA expression was increased in the gastric mucosa of HFD-fed mice at 12 weeks in contrast to that observed in CD-fed mice, in which it was constant (Fig. 3d and 3e). Consistent with the ectopic $C d x 2$ mRNA expression, the mRNA of Sox2, a transcription factor for stomach organogenesis [25], tended to be downregulated, indicating the development of intestinal metaplasia in the gastric mucosa in HFD-fed mice (Fig. 3e). Taken together, these results imply that HFD-feeding accelerates intestinal metaplasia.

\section{HFD feeding activates early leptin receptor signaling during gastric intestinal metaplasia}

Because of the early morphological alterations observed in the gastric mucosa, we examined the gene expression of stomach-specific hormones, peptides, and enzymes 1 week after HFD feeding. Leptin mRNA expression in particular was significantly higher in the stomach of HFD-fed mice; in contrast, ghrelin expression was lower in HFD-fed mice (Fig. 4a). The expression of other genes such as Atp $4 a$, Atp 4b, Pga, and $P g c$, which encode to $\mathrm{H}^{+} \mathrm{K}^{+}$-ATPase, pepsinogen $\mathrm{A}$, and pepsinogen $\mathrm{C}$, respectively, did not show significant differences between CD- and HFD-fed mice, although the expression of Atp $4 a$ and Atp $4 b$ tended to decrease (Fig. 4a). Normally, leptin is expressed in chief and parietal cells [26, 27]; however, HFD-fed mice exhibited strong leptin expression in the hyperplastic gastric epithelia (Fig. 4b and 4c). Even though the serum leptin concentration was similar between CD- and HFD-fed mice at 1 week after feeding (Fig. 4d), the leptin expression in the hyperplastic region of the stomach was consistent with the structural changes observed on H\&E stained sections at 1 week (Fig. 1b). The leptin expression continued to increase to 12 weeks post HFD feeding, after which the expression approximately recovered to the level observed in CD-fed mice at 20 weeks (Fig. 4b and 4c). Concomitant with the high leptin expression at 1 week, phosphorylation of ObRb, STAT3, Akt, and ERK, which are molecules associated with leptin receptor signaling, was detected in the gastric mucosa of HFD-fed WT mice (Fig. 5a). These molecules remained activated at 4 weeks after feeding. In contrast, leptin-deficient $o b / o b$ and ObR mutated $d b / d b$ mice did not show phosphorylated ObRb, and only exhibited slightly activated STAT3, Akt, and ERK. In support of the validity of these findings, the isotype-control $\mathrm{Ab}$ did not react specifically and no expression of $\mathrm{p}-\mathrm{ObRb}$ was detected in $d b / d b$ mice (Fig. 5b and $5 c$ ).

Chronic inflammation can trigger atrophic gastritis. IL-6 and IL-11, which are predominantly expressed in the stomach, modulate inflammatory responses during neoplastic progression [28, 29]. In particular, IL-11 expression increases in atrophic gastritis and in intestinal metaplasia of the fundic mucosa [30]. To identify potential initiators of intestinal metaplasia, we examined the expression of leptin, IL-6, and IL-11 in the gastric mucosa. Whereas leptin was expressed at 1 week after feeding, Il6 and Il11 mRNA levels did not increase in the gastric cardia of HFD-fed mice until 3 weeks after diet initiation (Fig. 6a). At 12 weeks, IL-11 expression accompanied an increased number of $\mathrm{CD} 45^{+}$infiltrated cells (Fig. $6 \mathrm{a}$ and $6 \mathrm{~b}$ ). These findings suggest that HFDinduced leptin expression and downstream activation precedes the induction of inflammatory cytokines during intestinal metaplasia.

\section{Lack of leptin signaling suppresses gastric intestinal metaplasia}

HFD feeding activated leptin signaling, leading to intestinal metaplasia in WT mice. Conversely, the absence of leptin signaling should therefore suppress HFD-induced gastric pathology. To investigate the role of leptin signaling in the development of intestinal metaplasia, we examined gastric mucosal changes in leptin-deficient $o b / o b$ mice and leptin receptor-mutated $d b / d b$ mice. The $o b / o b$ and $d b / d b$ mice showed a higher body weight than did WT mice; however, no significant difference in body weights was observed between CD- and HFD-fed mice at 1 week after feeding (Additional file 3: Figure S1a). The $o b / o b$ and $d b / d b$ mice fed the CD for 1 week exhibited hyperinsulinemia, whereas only HFD-fed $o b / o b$ mice showed increased insulin levels. HFD-fed $d b / d b$ mice showed insulin levels similar to those of CD-fed $d b / d b$ mice, because of their insulin resistance (Additional file 3: Figure S1b). The $d b / d b$ mice also exhibited hyperleptinemia and hypergluconemia. However, the non-esterified fatty acid (NEFA) concentration did not vary among WT, $o b / o b$, and $d b / d b$ mice fed with either CD or HFD (Additional file 3: Figure S1b). Histopathological analysis revealed that compared to the WT mice, $o b / o b$ and $d b / d b$ mice that were obese and insulin- or leptin- resistant showed few morphological changes such as hyperplasia of the gastric cardial mucosa at 1 week after initiation of HFD feeding (Fig. 7a). Mucosal height analysis was consistent with the histological findings (Fig. 7c). Furthermore, immunohistochemical analysis revealed increased colocalization of $\mathrm{Cdx} 2$ and leptin in the gastric mucosa of WT mice fed the HFD for 1 week (Fig. 8a), whereas $d b / d b$ 


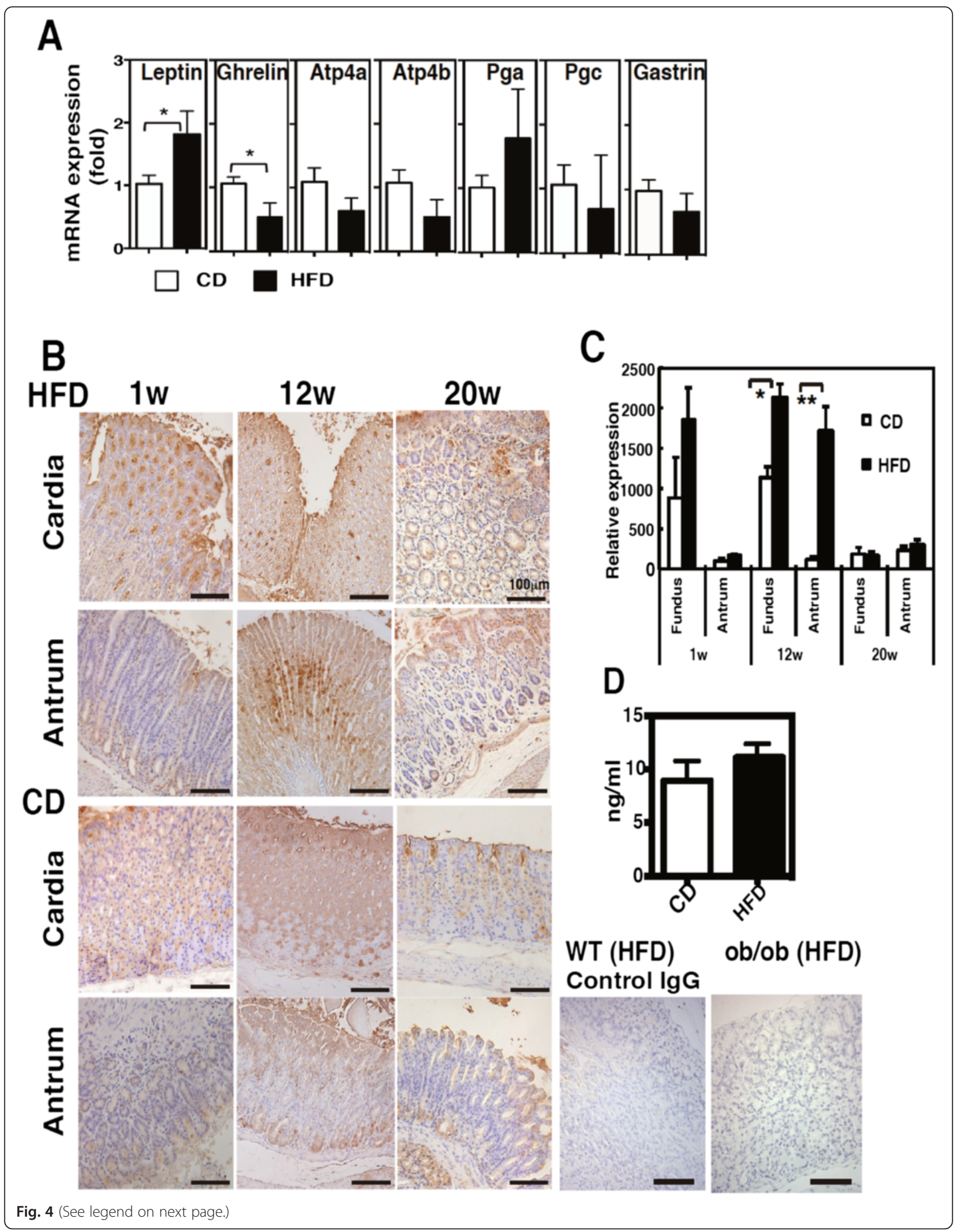


(See figure on previous page.)

Fig. 4 Enhancement of gastric leptin expression in the early period of HFD feeding. a Gene expression of gastric-specific molecules at 1 week after CD and HFD feeding. b Gastric sections stained for leptin in mice fed CD or HFD for 1, 12, and 20 weeks. c Quantification of leptin expression in (b). The data are presented as the relative expression at each time-point to the expression level in the antrum of CD-fed mice after 1 week. $\mathbf{d}$ Serum leptin concentration in mice fed CD and HFD for 1 week. The values represent the means \pm SD of 5 mice. The results were analyzed by the Mann-Whitney $U$ test. ${ }^{*} p<0.05,{ }^{* *} p<0.01$

mice did not show Cdx2 expression in leptin-positive cells. In contrast, $o b / o b$ mice showed little Cdx2 and no leptin expression. Similarly, co-localization of phosphorylated $\mathrm{ObRb}$ and $\mathrm{Cdx} 2$ was detected in HFD-fed WT mice, but not in HFD-fed $o b / o b$ or $d b / d b$ mice, which showed only some phosphorylation of $\mathrm{ObRb}$ or $\mathrm{Cdx} 2$, respectively. CD-fed ob/ob and $\mathrm{db} / \mathrm{db}$ mice showed a drastic increase in body weight but only slight hyperplasia in the gastric mucosa compared to WT mice at 3 weeks (Fig. 7b and 7c). Despite having higher body weights, $o b / o b$ and $d b / d b$ mice fed the HFD for 3 weeks exhibited less hyperplasia than did WT mice fed the HFD for 20 weeks. After 20 weeks of HFD feeding, the WT mice presented an irregular and fused structure in the cardia (Fig. 7b). HFD feeding did not increase the expression of $\mathrm{Cdx} 2$ and Muc2 in the gastric mucosa of $o b / o b$ and $d b / d b$ mice (Fig. $8 \mathrm{~b}$ ). These results suggest that leptin signaling in the stomach is an important factor that leads to metaplastic pathology in obesity-related gastritis.

\section{Discussion}

This study presents the first evidence supporting the theory that HFD-induced enhanced leptin receptor signaling in the gastric mucosa causes atrophic gastritis in a murine model. We found that HFD feeding triggers leptin production and the activation of leptin-ObR signaling in the gastric mucosa, promoting atrophic gastritis and intestinal metaplasia. Given the higher frequency of gastritis in obese patients [31,32], our results substantiate the role of leptin receptor signaling in obesity-induced atrophic gastritis. H. pylori infection is considered a major cause of chronic gastritis and GC [33, 34]; however, very few $H$. pylori-infected patients develop GC [35]. Furthermore, the frequency of gastritis is significantly higher in morbidly obese patients, whereas the prevalence of $H$. pylori infection is similar in obese and non-obese individuals [2]. Thus, obesity is an important factor accounting for the prevalence of histologic gastritis and the transformation of gastric mucosal cells in addition to $H$. pylori infection.

In addition to adipose tissue, the placenta [36] and mammary glands [37, 38] also produce leptin, which supports trophoblast cell proliferation to regulate fetal growth and development $[39,40]$ and the development of the mammary gland, respectively. In those tissues, leptin is produced in both normal and malignant cells, and its overexpression has been demonstrated in neoplastic cells [36, 41]. Elevated expression of leptin and
ObRb is associated with faster tumor recurrence and mortality in human grade-III invasive breast tumors $[42,43]$. Tumor cells derived from MMTV-Wnt1 mice, a widely used model of mammary tumors, show decreased growth in $o b / o b$ mice compared with cells from diet-induced obese mice that have functional leptin signaling [44]. Our data show that $o b / o b$ and $d b / d b$ mice show no activation of the ObR, a marked decrease in the activation of STAT3, Akt, and ERK (Fig. 5a), and exhibit less progression of gastric hyperplasia even though these mice are more obese than HFD-fed WT mice (Fig. 7). Furthermore, $o b / o b$ and $d b / d b$ mice do not spontaneously develop gastric tumors although these mice exhibit extraordinary obesity. Thus, the results of our study together with those of the previous reports imply that leptin signaling is critically involved in the control of epithelium development in a variety of tissues. Although the significance of leptin expression and its signaling in the stomach remains uncertain, considering the constitutive expression of leptin and ObRb in the stomach $[45,46]$, leptin might be necessary for the maintenance of gastric mucosal homeostasis.

Leptin is considered to represent a key player in obesity-associated gastrointestinal malignancies because of its roles in angiogenesis, apoptosis, cell proliferation, and cell migration, which support the milieu of tumor development and progression [17]. Recently, leptin was shown to contribute to mucin production and the formation of gastrointestinal neoplasms by modulating mTOR-, STAT3-, and ERK-dependent pathways [47] in addition to PKC-, PI3K-, and MAPK-dependent pathways $[48,49]$. The mechanisms underlying the induction of gastric atrophy are not defined; however, transcription factors responsible for cell differentiation have been reported to be potently involved in gastric tumorigenesis. Transcription factors such as $\mathrm{Cdx} 2$ and Sox 2 are critical for cell self-renewal and the maintenance of cells in appropriate proportions [50]. Sox 2 is a primary regulator of gastric differentiation that maintains gastric mucosal features and regulates the expression of gastric mucus genes, such as Muc5ac [51], and it is downregulated during the development of gastric adenocarcinoma [52, 53]. In contrast, $\mathrm{Cdx} 2$ is essential for intestinal epithelium differentiation to regulate the expression of Muc2 [54, 55] and Tff3 [56], and it is upregulated during the progression of gastric tumors [57]. Recently, the binding of phosphorylated STAT3 to the $\mathrm{Cdx} 2$ promoter region was shown to 


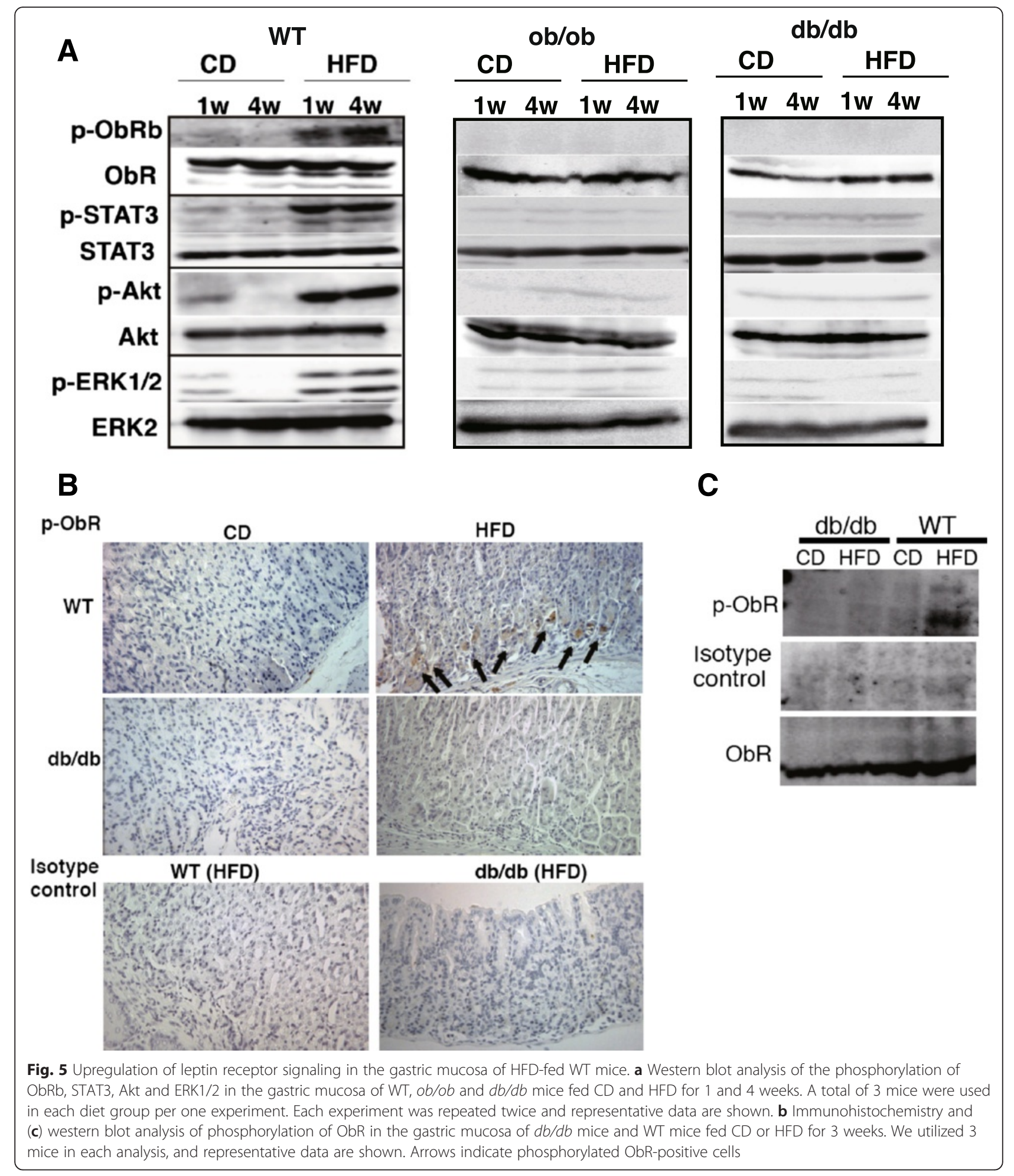

upregulate $\mathrm{Cdx} 2$ but downregulate Sox 2 in two gastric cell lines, MKN45 and NUGC4 [58]. In this study, we showed that HFD feeding induces $\mathrm{Cdx} 2$ and Muc2 expression associated with increased leptin levels (Figs. 3 and 8), suggesting the possibility that leptin acts to suppress cellular protection against gastric mucosal malignancies in the early stage of atrophic gastritis.

Atrophic gastritis is characterized by an alteration of the differentiation of gastric mucosal cells such as the loss of parietal and chief cells and replacement of the 


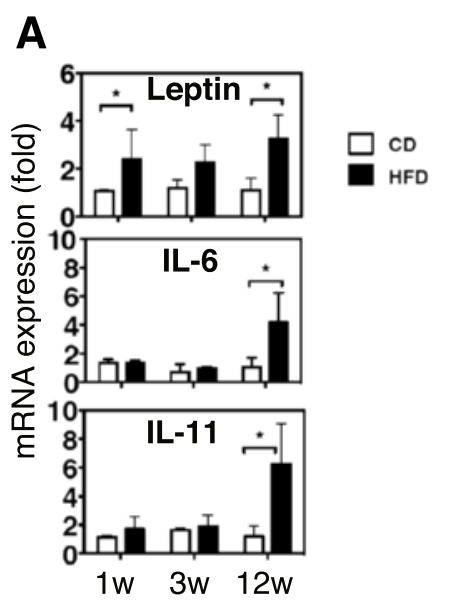

\section{IL-11 CD45 DAPI}

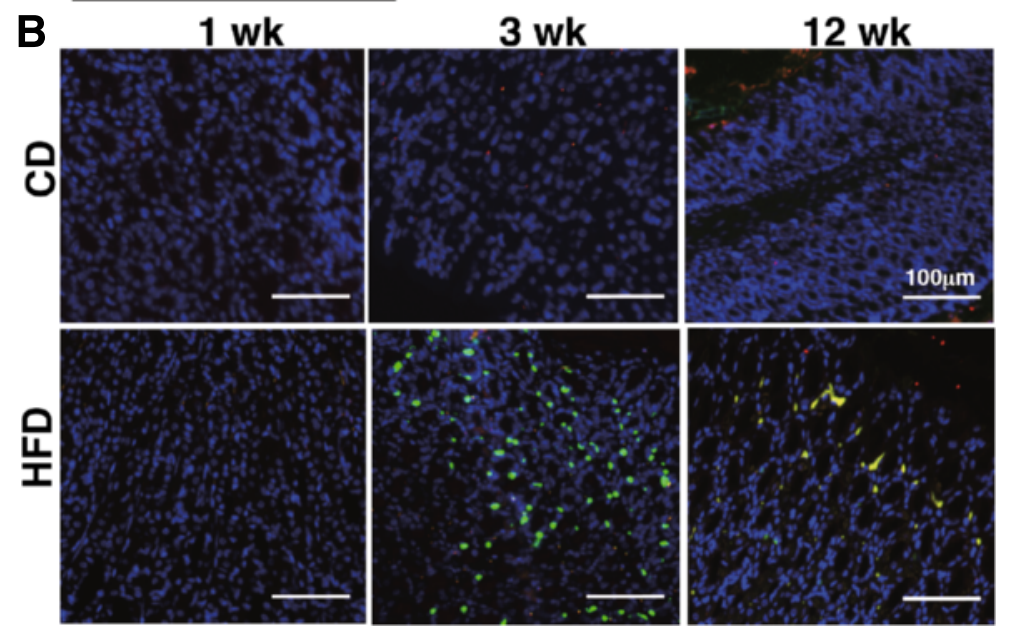

Fig. 6 Delayed induction of proinflammatory cytokines in the gastric mucosa after HFD-feeding. a Gene expression of leptin, II6, and II11 in the gastric mucosa of CD- and HFD-fed mice after 1, 3, and 12 weeks. The values represent the means \pm SD of 4 mice. The results were analyzed by the Kruskal-Wallis test. ${ }^{*} p<0.05, p<0.01$. $\mathbf{b}$ Immunohistological staining of the stomach sections of the CD and HFD-fed mice with Abs against IL-11 and CD45

destroyed glandular structure with a diffuse intestinal mucous metaplasia [59]. Variations in the pathology of atrophic gastritis have been reported to some degree in genetically engineered mice such as Atp4a $\mathrm{a}^{-/-}$and gastrin ${ }^{-1-}$ mice, which are used as models of parietal and glandular cell loss. However, Atp4a ${ }^{-1-}$ mice exhibit the same expression levels of Muc2 and Tff3 in the gastric mucosa as control Atp $4 \mathrm{a}^{+/+}$mice, indicating incomplete intestinalization of the gastric mucosa in these mice [60]. Gastrin is secreted from G-cells to stimulate acid secretion and cell proliferation of the fundic mucosa [61]. Gastrin ${ }^{-1-}$ mice develop antral gastric neoplasia with increased levels of Muc2 and villin (an intestinal-specific actin bundling protein) in the gastric mucosa in the presence of gastric inflammation but not in the fundus $[62,63]$. As proinflammatory cytokines involved in atrophic gastritis, IL- 6 and IL-11 cause an inflammatory response in the stomach and play important roles in angiogenesis and cell proliferation during the progression of neoplasia [28, 29]; thus, they are used as biomarkers of aggressive tumors [64]. In particular, IL-11, which is mainly expressed in the fundic mucosa, might play a pivotal role in atrophic gastritis and the progression of GC $[30,65]$. Chronic treatment of WT mice with recombinant IL-11 induces atrophy in the gastric fundus, including the cardia, with reduced parietal cells and highly phosphorylated STAT3, but no features of intestinalization of the gastric mucosa such as the appearance of goblet cells, Muc2, and Cdx2. These reports raise the question of which molecules are directly involved in the atrophy of the gastric mucosa associated with metaplasia. In our study, the increase of gastric leptin expression is observed during the early period after the initiation of HFD feeding and its 


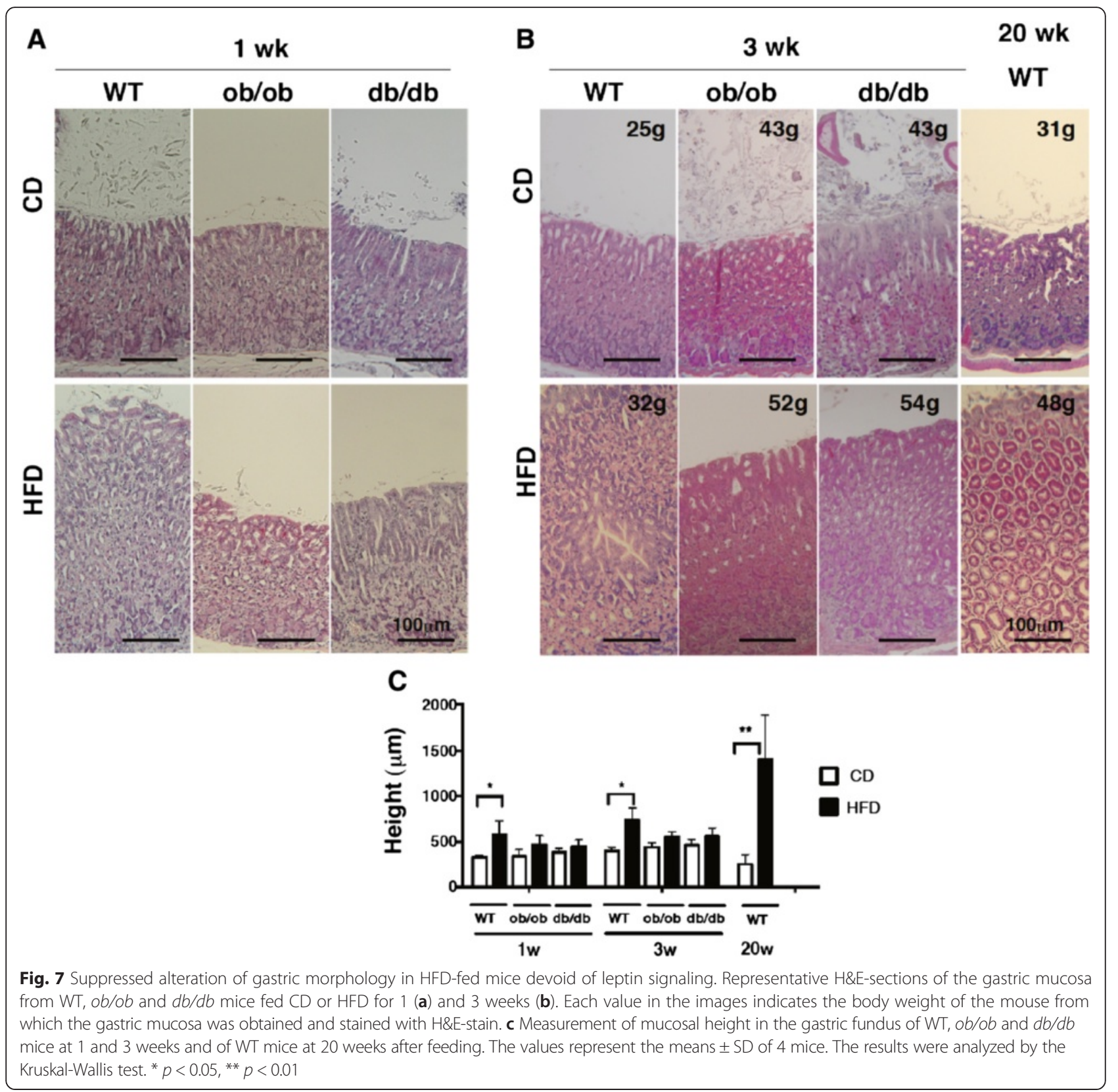

subsequent reduction is consistent with the loss of normal parietal and chief cells, which constitutively produce leptin and ObR [26, 27], in the gastric mucosa of HFD-fed mice in accordance with the development of intestinal metaplasia after 20 weeks of HFD feeding (Figs. 1, 2 and 3). Our results might therefore directly indicate the involvement of leptin receptor signaling in the initiation of obese-associated gastric atrophy.

The involvement of gastric leptin in diet-induced obesity-associated gastric atrophy has not previously been investigated, although the elevation of serum leptin contributes to tumorigenesis in the stomach of obese mice infected with $H$. felis [66]. In the current study, we showed rapid (1 week) mucosal morphological changes in the gastric cardia (Fig. 1b) in accordance with high expression of gastric leptin at this time (Fig. 4d). Furthermore, prior to the production of IL-11, leptin expression in the cardial gastric mucosa increases, concurrent with the hyperplastic lesions observed in the early period after HFD feeding (Fig. 4b and 6). The localization of leptin-producing cells within cardial mucosal lesions occurs during the early stage of atrophy in HFD-fed mice. Furthermore, the increased leptin levels and activation of ObRb resulted in increased levels of phosphorylated STAT3 in the HFD-fed mice (Fig. 5a). Notably, because $o b / o b$ and $d b / d b$ mice do not transduce leptin receptor signaling and do not show 


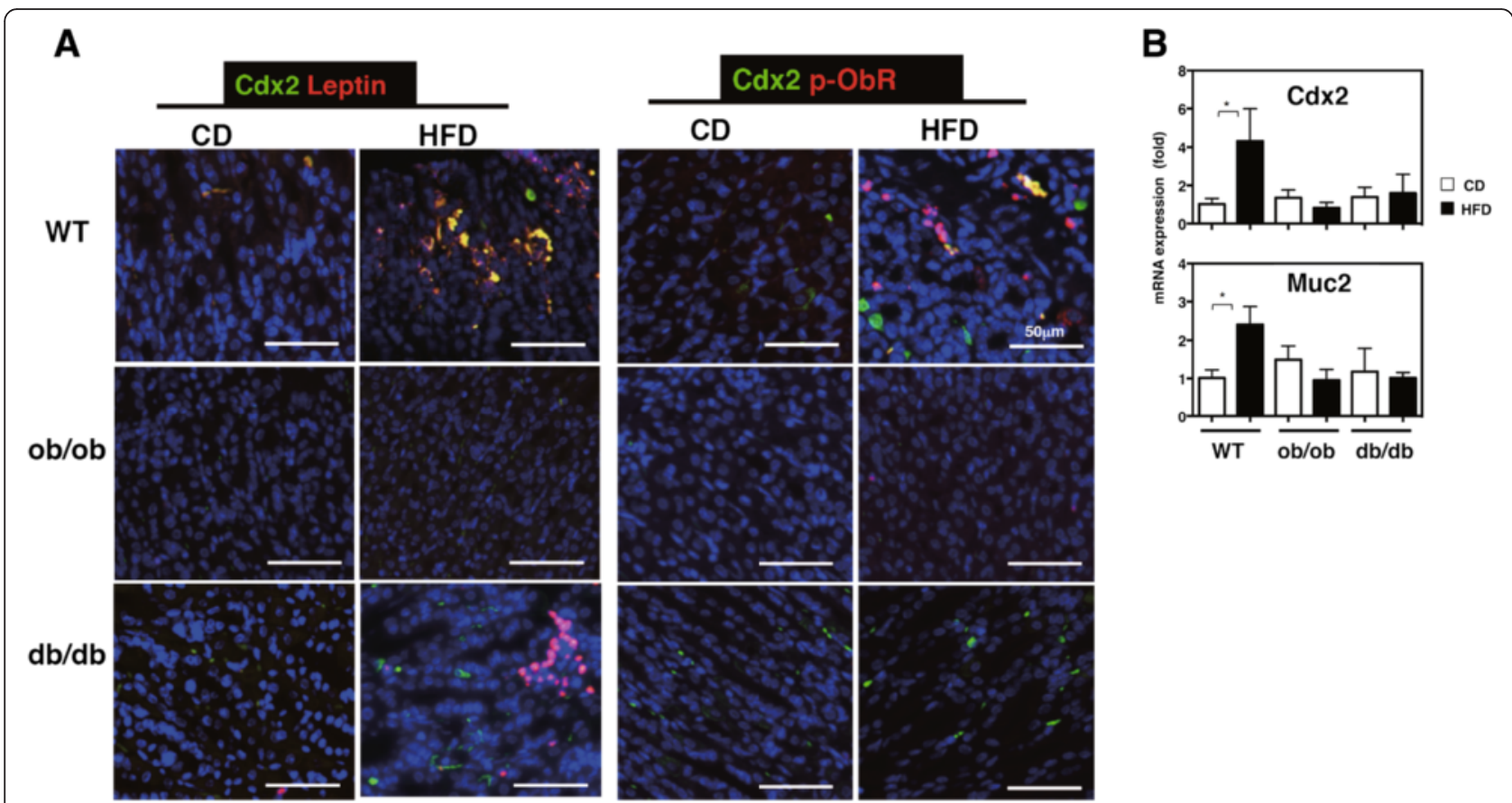

Fig. 8 Downregulation of intestinal epithelial markers in mice devoid of leptin signaling. a Immunohistological staining of the stomach sections of the CD and HFD-fed mice with Abs against leptin, Cdx2, and p-ObRb. $\mathbf{b}$ Gene expression of $C d x 2$ and Muc2 in the gastric mucosa of mice fed CD or HFD for 1 week. The values represent the means \pm SD of 4 mice. The results were analyzed by the Kruskal-Wallis test. ${ }^{*} p<0.01$

morphological alterations such as loss of glandular structure (Fig. 5a and 7), the elevation of gastric leptin by HFD feeding might initiate a reduction of glandular structure by diffuse metaplasia, i.e., a loss of parietal and chief cells. Since most parietal and chief cells residing in the fundic mucosa of the stomach express leptin and ObRb $[26,45,46]$, it would be interesting to investigate how these cells respond to food-based stimulants such as fatty acids in the HFD.

In summary, we demonstrated the development of atrophic gastritis using a murine model of diet-induced obesity with an enhanced leptin-ObRb signaling pathway. The expression and unique localization of the leptin-ObR signaling pathway predominantly indicates a role in the early phase of human GC. The significance of this study lies in the potential and invaluable use of leptin and ObR as biomarkers or as new therapeutic targets for the diagnosis and treatment of atrophic gastritis.

\section{Conclusion}

In this study, we show that diet-induced obese WT mice exhibit overexpression of leptin and activation of leptin receptor signaling in the gastric mucosa, leading to atrophic gastritis with intestinal metaplasia of the gastric mucosa. These pathological features are less severe in $o b / o b$ and $d b / d b$ mice, which lack leptin receptor signaling, than in the WT mice. Therefore, leptin receptor signaling in the stomach is a critical checkpoint for the onset of gastric neoplasia, and preventive therapeutics targeting gastric leptin receptor signaling might be developed against GC.

\section{Additional files}

Additional file 1: Table S1. Antibody list: Antibodies used for western blotting and immunohistochemistry. (DOCX 127 kb)

Additional file 2: Table S2. Primers used for quantitative PCR. (DOCX 100 kb)

Additional file 3: Figure S1. Alteration of index associated with obesity. Body weight (A), insulin, leptin, glucose and NEFA in sera (B) in CD- and HFD-fed WT, ob/ob and db/db mice were measured 1 week after feeding. Results were analyzed by the Kruskal Wallis test. ${ }^{*} p<0.01$. (EPS $1473 \mathrm{~kb}$ )

\section{Abbreviations}

CD: Control diet; DTT: Dithiothreitol; EDTA: Ethylenediaminetetraacetic acid; ELISA: Enzyme-linked immunosorbent assay; GC: Gastric carcinoma; HFD: High fat diet; LMD: Laser-capture microdissection; NEFA: Non-esterified fatty acid; WT: Wild-type.

\section{Competing interests}

The authors declare they have no competing interests.

\section{Authors' contributions}

$\mathrm{K} \mathrm{I}-\mathrm{O}$ conceived and designed the project and executed the experiments and wrote the manuscript. KT, LT, KS, and SA assisted with the animal care and plasma assay experiments, TH and SM set up LMD. SO and YM analyzed the data and provided constructive discussion. All authors read and approved the final manuscript. 


\section{Acknowledgments}

This work was supported by Grants-in-Aid for Scientific Research (C) from the Ministry of Education, Culture, Sports, Science and Technology of Japan (23590272 and 26461391) and a PUH Research Grant Program (A)(Prefectural University of Hiroshima) awarded to K. I-O. We would like to thank Professor Takao Shimizu, Professor Masashi Mizokami (NCGM), Dr. Masanobu Nanno (Yakult Honsha Co. Ltd), and Professor Masao Mitsuyama (Kyoto University) for their continuous encouragement and support.

\section{Author details}

'Research Institute, National Center for Global Health and Medicine (NCGM), 1-21-1, Toyama Shinjuku, Tokyo 162-0052, Japan. ${ }^{2}$ Division of Endocrinology and Metabolism, Department of Developmental Physiology, National Institute for Physiological Sciences (NIPS), 38 Nishigonaka Myodaiji, Okazaki, Aichi 444-8585, Japan. ${ }^{3}$ Division of Host Defense, Department of Life Sciences, Faculty of Life and Environmental Sciences, Prefectural University of Hiroshima, 562 Nanatsuka, Shobara, Hiroshima 727-0023, Japan. ${ }^{4}$ Yakult Central Institute for Microbiological Research, 5-11 Izumi, Kunitachi, Tokyo 186-8650, Japan. ${ }^{5}$ Section of Oncopathology and Regenerative Biology, Department of Pathology, Faculty of Medicine, University of Miyazaki, 5200 Kihara, Kiyotake, Miyazaki 889-1692, Japan.

\section{Received: 21 August 2015 Accepted: 26 January 2016}

\section{Published online: 02 February 2016}

\section{References}

1. Vannella L, Lahner E, Annibale B. Risk for gastric neoplasias in patients with chronic atrophic gastritis: a critical reappraisal. World J Gastroenterol. 2012;18:1279-85.

2. Dutta SK, Arora M, Kireet A, Bashandy H, Gandsas A. Upper gastrointestinal symptoms and associated disorders in morbidly obese patients: a prospective study. Dig Dis Sci. 2009;54:1243-6.

3. Renshaw AA, Rabaza JR, Gonzalez AM, Verdeja JC. Helicobacter pylori infection in patients undergoing gastric bypass surgery for morbid obesity Obes Surg. 2001;11:281-3.

4. Tanaka M, Fukui M, Kuroda M, Yamazaki M, Hasegawa G, Oda Y, et al. Pepsinogen I/II ratio is related to glucose, triacylglycerol, and uric acid levels. Nutrition. 2012;28:418-21.

5. Torisu T, Matsumoto T, Takata Y, Ansai T, Soh I, Awano S, et al. Atrophic gastritis, but not antibody to Helicobacter pylori, is associated with body mass index in a Japanese population. J Gastroenterol. 2008;43:762-6.

6. Watabe H, Mitsushima T, Derakhshan MH, Yamaji Y, Okamoto M, Kawabe T, et al. Study of association between atrophic gastritis and body mass index: a cross-sectional study in 10,197 Japanese subjects. Dig Dis Sci. 2009;54:988-95.

7. O'Doherty MG, Freedman ND, Hollenbeck AR, Schatzkin A, Abnet CC. A prospective cohort study of obesity and risk of oesophageal and gastric adenocarcinoma in the NIH-AARP Diet and Health Study. Gut. 2012;61:1261-8.

8. Cho Y, Lee DH, Oh HS, Seo JY, Lee DH, Kim N, et al. Higher prevalence of obesity in gastric cardia adenocarcinoma compared to gastric non-cardia adenocarcinoma. Dig Dis Sci. 2012;57:2687-92.

9. Lagergren J, Bergstrom R, Nyren O. Association between body mass and adenocarcinoma of the esophagus and gastric cardia. Ann Intern Med. 1999;130:883-90.

10. Bhandari A, Crowe SE. Helicobacter pylori in gastric malignancies. Curr Gastroenterol Rep. 2012;14:489-96.

11. Chung WK, Leibel RL. The links between obesity, leptin, and prostate cancer. Cancer J. 2006;12:178-81.

12. Friedman JM, Halaas $\mathrm{JL}$. Leptin and the regulation of body weight in mammals. Nature. 1998;395:763-70.

13. Tartaglia LA, Dembski M, Weng X, Deng N, Culpepper J, Devos R, et al. Identification and expression cloning of a leptin receptor. OB-R Cell. 1995:83:1263-71.

14. La Cava A, Matarese $G$. The weight of leptin in immunity. Nat Rev Immunol. 2004:4:371-9.

15. Guilmeau S, Buyse M, Bado A. Gastric leptin: a new manager of gastrointestinal function. Curr Opin Pharmacol. 2004;4:561-6.

16. Ishikawa M, Kitayama J, Nagawa H. Expression pattern of leptin and leptin receptor (OB-R) in human gastric cancer. World J Gastroenterol. 2006;12:5517-22.

17. Howard JM, Pidgeon GP, Reynolds JV. Leptin and gastro-intestinal malignancies. Obes Rev. 2010;11:863-74.
18. Zhao L, Shen ZX, Luo HS, Shen L. Possible involvement of leptin and leptin receptor in developing gastric adenocarcinoma. World J Gastroenterol. 2005;11:7666-70.

19. Inagaki-Ohara K, Mayuzumi H, Kato S, Minokoshi Y, Otsubo T, Kawamura Yl, et al. Enhancement of leptin receptor signaling by SOCS3 deficiency induces development of gastric tumors in mice. Oncogene. 2014;33:74-84.

20. Myers MG, Cowley MA, Munzberg H. Mechanisms of leptin action and leptin resistance. Annu Rev Physiol. 2008;70:537-56.

21. Martinez V, Curi AP, Torkian B, Schaeffer JM, Wilkinson HA, Walsh JH, et al. High basal gastric acid secretion in somatostatin receptor subtype 2 knockout mice. Gastroenterology. 1998;114:1125-32.

22. Inagaki-Ohara K, Chinen T, Matsuzaki G, Sasaki A, Sakamoto Y, Hiromatsu K, et al. Mucosal T cells bearing TCRgammadelta play a protective role in intestinal inflammation. J Immunol. 2004;173:1390-8.

23. Inagaki-Ohara K, Sasaki A, Matsuzaki G, Ikeda T, Hotokezaka M, Chijiiwa K, et al. Suppressor of cytokine signalling 1 in lymphocytes regulates the development of intestinal inflammation in mice. Gut. 2006;55:212-9.

24. Lauren P. The Two Histological Main Types of Gastric Carcinoma: Diffuse and So-Called Intestinal-Type Carcinoma. An Attempt at a Histo-Clinical Classification. Acta Pathol Microbiol Scand. 1965;64:31-49.

25. Chalmers AD, Slack JM, Beck CW. Regional gene expression in the epithelia of the Xenopus tadpole gut. Mech Dev. 2000;96:125-8.

26. Cinti S, Matteis RD, Pico C, Ceresi E, Obrador A, Maffeis C, et al. Secretory granules of endocrine and chief cells of human stomach mucosa contain leptin. Int J Obes Relat Metab Disord. 2000;24:789-93.

27. Mix H, Widjaja A, Jandl O, Cornberg M, Kaul A, Goke M, et al. Expression of leptin and leptin receptor isoforms in the human stomach. Gut. 2000;47:481-6.

28. Howlett M, Menheniott TR, Judd LM, Giraud AS. Cytokine signalling via gp130 in gastric cancer. Biochim Biophys Acta. 2009;1793:1623-33.

29. Matsuo K, Oka M, Murase K, Soda H, Isomoto H, Takeshima F, et al. Expression of interleukin 6 and its receptor in human gastric and colorectal cancers. J Int Med Res. 2003;31:69-75.

30. Howlett M, Chalinor HV, Buzzelli JN, Nguyen N, van Driel IR, Bell KM, et al. IL-11 is a parietal cell cytokine that induces atrophic gastritis. Gut. 2012;61:1398-409.

31. Yamamoto $S$, Watabe $K$, Takehara T. Is obesity a new risk factor for gastritis? Digestion. 2012:85:108-10.

32. Delgado-Aros S, Locke 3rd GR, Camilleri M, Talley NJ, Fett S, Zinsmeister AR, et al. Obesity is associated with increased risk of gastrointestinal symptoms: a population-based study. Am J Gastroenterol. 2004;99:1801-6.

33. Coussens LM, Zitvogel L, Palucka AK. Neutralizing tumor-promoting chronic inflammation: a magic bullet? Science. 2013;339:286-91.

34. Ahmed N, Sechi LA. Helicobacter pylori and gastroduodenal pathology: new threats of the old friend. Ann Clin Microbiol Antimicrob. 2005;4:1.

35. Fox JG, Wang TC. Inflammation, atrophy, and gastric cancer. J Clin Invest. 2007;117:60-9.

36. Masuzaki H, Ogawa Y, Sagawa N, Hosoda K, Matsumoto T, Mise H, et al. Nonadipose tissue production of leptin: leptin as a novel placenta-derived hormone in humans. Nat Med. 1997;3:1029-33.

37. Smith-Kirwin SM, O'Connor DM, De Johnston J, Lancey ED, Hassink SG, Funanage VL. Leptin expression in human mammary epithelial cells and breast milk. J Clin Endocrinol Metab. 1998;83:1810-3.

38. Aoki N, Kawamura M, Matsuda T. Lactation-dependent down regulation of leptin production in mouse mammary gland. Biochim Biophys Acta. 1999;1427:298-306.

39. Cameo P, Bischof $P$, Calvo JC. Effect of leptin on progesterone, human chorionic gonadotropin, and interleukin- 6 secretion by human term trophoblast cells in culture. Biol Reprod. 2003;68:472-7.

40. Henson MC, Castracane VD. Leptin in pregnancy: an update. Biol Reprod. 2006;74:218-29.

41. Hu X, Juneja SC, Maihle NJ, Cleary MP. Leptin-a growth factor in normal and malignant breast cells and for normal mammary gland development. J Natl Cancer Inst. 2002;94:1704-11.

42. Garofalo C, Koda M, Cascio S, Sulkowska M, Kanczuga-Koda L, Golaszewska J, et al. Increased expression of leptin and as a marker of breast cancer progression: possible role of obesity-related stimuli. Clin Cancer Res. 2006;12:1447-53.

43. Maccio A, Madeddu C, Gramignano G, Mulas C, Floris C, Massa D, et al. Correlation of body mass index and leptin with tumor size and stage of disease in hormone-dependent postmenopausal breast cancer: preliminary results and therapeutic implications. J Mol Med (Berl). 2010;88:677-86.

44. Zheng Q, Dunlap SM, Zhu J, Downs-Kelly E, Rich J, Hursting SD, et al. Leptin deficiency suppresses MMTV-Wnt-1 mammary tumor growth in obese mice and abrogates tumor initiating cell survival. Endocr Relat Cancer. 2011;18:491-503. 
45. Bado A, Levasseur S, Attoub S, Kermorgant S, Laigneau JP, Bortoluzzi MN, et al. The stomach is a source of leptin. Nature. 1998;394:790-3.

46. Sobhani I, Bado A, Vissuzaine C, Buyse M, Kermorgant S, Laigneau JP, et al. Leptin secretion and leptin receptor in the human stomach. Gut. 2000;47:178-83.

47. Chang MS, Byeon SJ, Yoon SO, Kim BH, Lee HS, Kang GH, et al. Leptin, MUC2 and mTOR in appendiceal mucinous neoplasms. Pathobiology. 2012;79:45-53.

48. Plaisancie P, Ducroc R, El Homsi M, Tsocas A, Guilmeau S, Zoghbi S, et al. Luminal leptin activates mucin-secreting goblet cells in the large bowel. Am J Physiol Gastrointest Liver Physiol. 2006;290:G805-12.

49. El Homsi M, Ducroc R, Claustre J, Jourdan G, Gertler A, Estienne M, et al. Leptin modulates the expression of secreted and membrane-associated mucins in colonic epithelial cells by targeting PKC, PI3K, and MAPK pathways. Am J Physiol Gastrointest Liver Physiol. 2007;293:G365-73.

50. Al-Marzoqee FY, Khoder G, Al-Awadhi H, John R, Beg A, Vincze A, et al. Upregulation and inhibition of the nuclear translocation of Oct4 during multistep gastric carcinogenesis. Int J Oncol. 2012;41:1733-43.

51. Park ET, Gum JR, Kakar S, Kwon SW, Deng G, Kim YS. Aberrant expression of SOX2 upregulates MUC5AC gastric foveolar mucin in mucinous cancers of the colorectum and related lesions. Int J Cancer. 2008;122:1253-60.

52. Tsukamoto T, Inada K, Tanaka H, Mizoshita T, Mihara M, Ushijima T, et al. Down-regulation of a gastric transcription factor, Sox2, and ectopic expression of intestinal homeobox genes, $\mathrm{Cdx} 1$ and $\mathrm{Cdx2}$ : inverse correlation during progression from gastric/intestinal-mixed to complete intestinal metaplasia. J Cancer Res Clin Oncol. 2004;130:135-45.

53. Tsukamoto T, Mizoshita T, Mihara M, Tanaka H, Takenaka Y, Yamamura Y, et al. Sox2 expression in human stomach adenocarcinomas with gastric and gastric-and-intestinal-mixed phenotypes. Histopathology. 2005;46:649-58.

54. Mesquita P, Jonckheere N, Almeida R, Ducourouble MP, Serpa J, Silva E, et al. Human MUC2 mucin gene is transcriptionally regulated by $C d x$ homeodomain proteins in gastrointestinal carcinoma cell lines. J Biol Chem. 2003;278:51549-56.

55. Yamamoto $H$, Bai $Y Q$, Yuasa $Y$. Homeodomain protein CDX2 regulates goblet-specific MUC2 gene expression. Biochem Biophys Res Commun. 2003:300:813-8.

56. Shimada T, Koike T, Yamagata M, Yoneda M, Hiraishi H. Regulation of TFF3 expression by homeodomain protein CDX2. Regul Pept. 2007;140:81-7.

57. Mutoh H, Sakurai S, Satoh K, Tamada K, Kita H, Osawa H, et al. Development of gastric carcinoma from intestinal metaplasia in Cdx2-transgenic mice. Cancer Res. 2004;64:7740-7.

58. Cobler L, Pera M, Garrido M, Iglesias M, de Bolos C. CDX2 can be regulated through the signalling pathways activated by IL-6 in gastric cells. Biochim Biophys Acta. 1839;2014:785-92.

59. Rugge M, Correa P, Dixon MF, Fiocca R, Hattori T, Lechago J, et al. Gastric mucosal atrophy: interobserver consistency using new criteria for classification and grading. Aliment Pharmacol Ther. 2002;16:1249-59.

60. Judd LM, Andringa A, Rubio CA, Spicer Z, Shull GE, Miller ML. Gastric achlorhydria in H/K-ATPase-deficient (Atp4a(-/-)) mice causes severe hyperplasia, mucocystic metaplasia and upregulation of growth factors. J Gastroenterol Hepatol. 2005;20:1266-78.

61. Wang TC, Koh TJ, Varro A, Cahill RJ, Dangler CA, Fox JG, et al. Processing and proliferative effects of human progastrin in transgenic mice. J Clin Invest. 1996;98:1918-29.

62. Friis-Hansen L, Sundler F, Li Y, Gillespie PJ, Saunders TL, Greenson JK, et al. Impaired gastric acid secretion in gastrin-deficient mice. Am J Physiol. 1998;274:G561-8.

63. Zavros Y, Eaton KA, Kang W, Rathinavelu S, Katukuri V, Kao JY, et al. Chronic gastritis in the hypochlorhydric gastrin-deficient mouse progresses to adenocarcinoma. Oncogene. 2005;24:2354-66.

64. Necula LG, Chivu-Economescu M, Stanciulescu EL, Bleotu C, Dima SO, Alexiu I, et al. IL-6 and IL-11 as markers for tumor aggressiveness and prognosis in gastric adenocarcinoma patients without mutations in Gp130 subunits. J Gastrointestin Liver Dis. 2012;21:23-9.

65. Ernst M, Thiem S, Nguyen PM, Eissmann M, Putoczki TL. Epithelial gp130/ Stat3 functions: an intestinal signaling node in health and disease. Semin Immunol. 2014;26:29-37.

66. Ericksen RE, Rose S, Westphalen CB, Shibata W, Muthupalani S, Tailor Y, et al. Obesity accelerates Helicobacter felis-induced gastric carcinogenesis by enhancing immature myeloid cell trafficking and TH17 response. Gut. 2014;63:385-94.

\section{Submit your next manuscript to BioMed Central and we will help you at every step:}

- We accept pre-submission inquiries

- Our selector tool helps you to find the most relevant journal

- We provide round the clock customer support

- Convenient online submission

- Thorough peer review

- Inclusion in PubMed and all major indexing services

- Maximum visibility for your research

Submit your manuscript at www.biomedcentral.com/submit
Ciomed Central 